\title{
WEBSITE DEVELOPMENT OF ENTERPRISE ERP BASED ON CONSTRUCTION INDUSTRY
}

\author{
Bhushan Mahajan ${ }^{1 *}$ \\ ${ }^{* 1}$ Yadaverao Tasgaonkar Institute Of Engineering \& Technology Mumbai University
}

*Corresponding Author: -

E-mail ID - bmahajan9488@hotmail.com

\begin{abstract}
: -
with the fast development of the information technology and enterprise business, the traditional desktop management system based on three-tier architecture could not satisfy the need of enterprises. In this project we develop a website for construction industry for a new solution of enterprises ERP which is based on construction field.
\end{abstract}

\section{(c) $(3)$ (1)}




\section{INTRODUCTION}

The quick development of information technology makes many traditional enterprises develop new information management system for satisfying the development of enterprises. These information systems include sale management system, finance management system, warehouse management system and so on. However, due to technical limitation, many information systems in professional fields would not fully achieve job requirements of the professional fields.

ERP system is a management platform of providing decision methods for the enterprise managers and staff. It is based on the information system and reflects the core idea of systematic management thinking. ERP help enterprises to change the backward management method and promote management benefit and profit of enterprises.

The traditional information systems of most enterprises are mostly based on the Client/Server or Browser/Server architecture. These systems that combine project management and manufacturing management are merely used to advance the business efficiency and management efficiency at the beginning. However, with the fast development of the enterprise business, these systems could not satisfy the development of the enterprise business. So the enterprises want to develop new information system.

In this project, we developed the original information system and bring forward a new solution of enterprises ERP that is based construction industry.

\section{Standard Procurement Cycle}

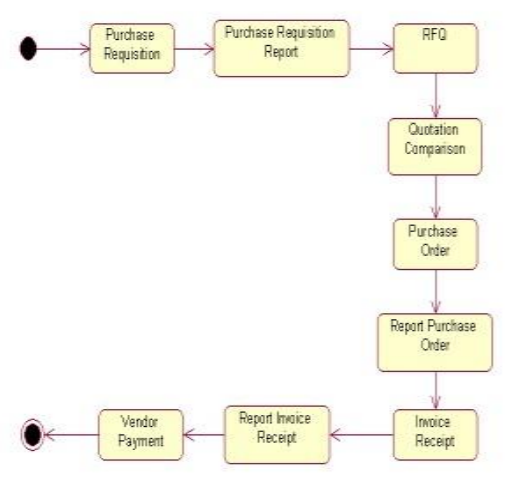

\section{MODULES}

\section{Senior Manager:}

a) A Manager is the main person of system whose job is to pass the bill

b) Without permission of manager there can't be any bill passing

c) A manager has a key authority for operations

d) All the modules have to report to manager

e) Only a manager can terminate the process

f) A manager decides the Budget of construction

\section{Junior Manager:}

g) A Junior manager has all the choices of selecting the material

h) All the modules have to report to Junior manager

i) A Junior manager decides the number of contractor

j) A Junior manager decides which material to choose for construction

k) A Junior manager decides the quality of construction

\section{Contractor}

I) A contractor is a person who accepts the contracts

m) A contractor is a person who actually does the work of construction

n) A contractor does construction with the help of vendors

\section{Finance Department}

o) A finance department does all the financial tasks

p) A finance department makes payment for the contract based on deadlines

q) A finance department reports to the manager about transections

\section{Site Engineer}

r) Site Engineers are those who keeps an eye on the construction

s) These reporters report to the Financial department and to the manager about the status of work.

\section{Control Department}

a) Control Department controls the employee database

b) Control Department has authority to add, update, Delete the employees 


\section{FORMS AND INSIDES}

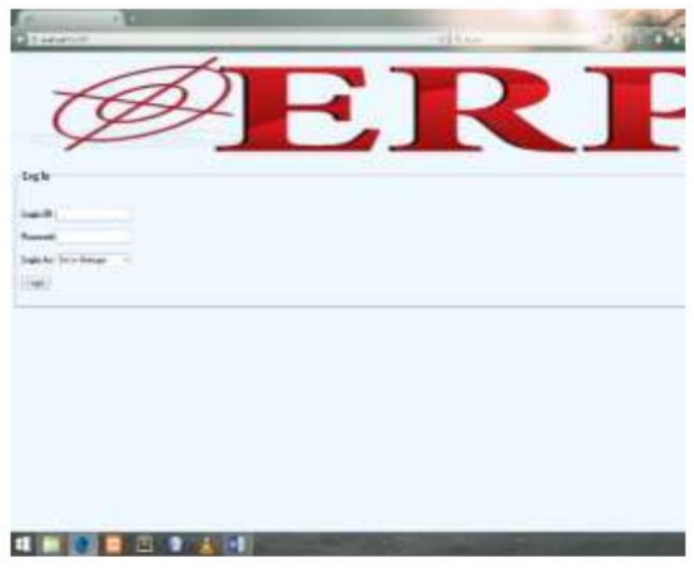

A login form accepts following inputs:

Login

1.Login ID

2.Password and

3.Authority

A Login redirects the valid user to following Sections:

1. Senior Manager

2. Manager

3. Site engineer

4. Contractor

5. Control department

6. Finance Department

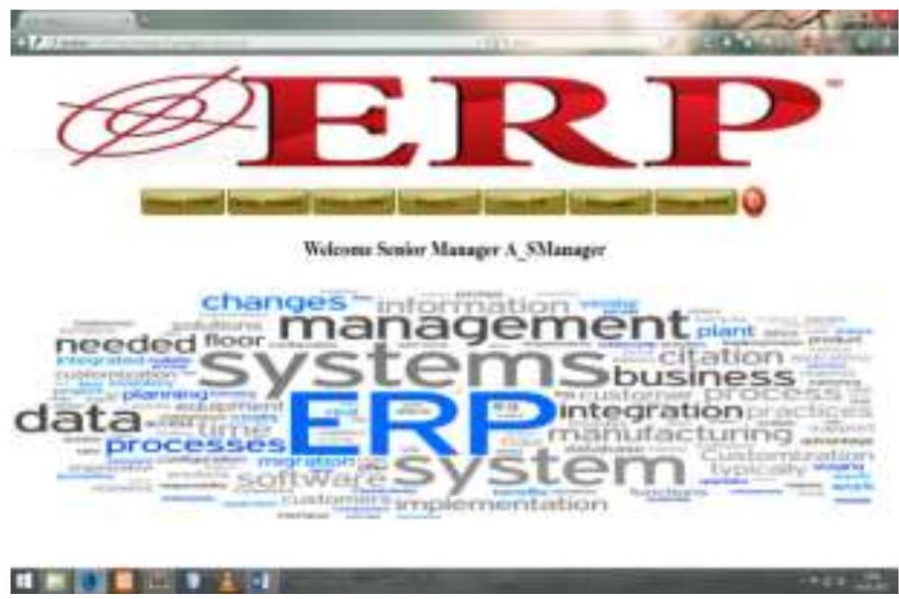

Key operations:

Senior Manager

1.Create Order

a.Work Order

b.Service Order

c.Purchase Order

\section{Order History}

a. Assigned Order

b. Closed Order

c. All Orders

d. Search

i. Search by Order Number

ii. Search by Order Type

iii. Search by Manager ID

\section{Reportsa.}


Incoming Reports

b.Search Reports

i.Report ID

ii. Sender ID

iii. Order Number

\section{User DB}

a.Senior Manager

b.Manager

c.Contractor

d.Site engineer

e.Finance Department

f.Control Department

g.All Employees

\section{h.Search}

i.Employee ID

ii.Employee Region

\section{Message}

a.New Massage(Create Message)

b.Incoming Message

c.All Message

i.Message ID

ii.Sender ID

\section{Change Password}

\section{Log Off}

\section{Key Operations}

\section{New Order}

\section{Create Order}

a.Work Order

b.Purchase Order

c.Service Order

\section{Current Order}

\section{Assign Resources}

\section{Quotation}

a.Order Number

b.All Quotations

c.Search Quotations

\section{User Database}

a.Senior Manager

b.Manager

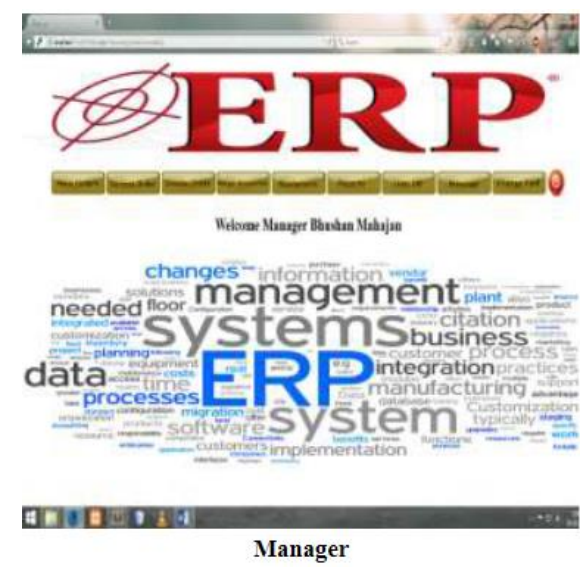


c.Site Engineer

d.Contractor

e.Finance department

f.Control Department

\section{Report}

a.Generate Report

b.Site Engineer report

c.Finance Department Report

d.My Report

e.Search Report

\section{Message}

a.New Message

b.Incoming Message

c.Search Messages

\section{Change Password}

\section{Log Off}

Key Operations

1.New Order

\section{Current Order}

\section{Quotations}

a)Create

b)History

c)Search

\section{Message}

a)New Message

b)Incoming Message

c)Search Message

\section{Change Password} 6.Log Off
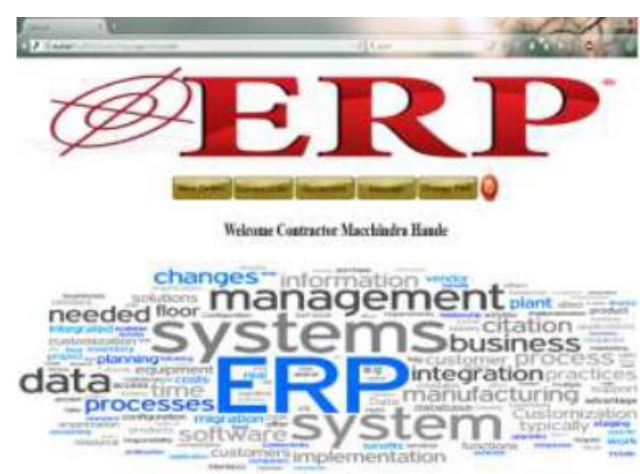

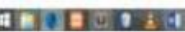

Contractor

Key Operations

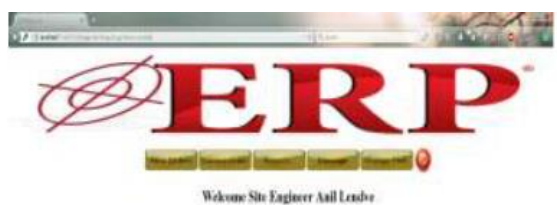

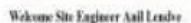

changes-infȫütionent needed SVSten Sbusiness datarem $\mathrm{m}$ m data $E \geqslant$ integration -processes I ISYStem

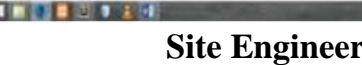


Key Operations

1.New Order

\section{Current Order}

\section{Report}

a)Generate report

b)All Report

\section{Message}

a)New Message

b)Incoming Message

c)Search Message

\section{Log Off}

Key Operations

1.Reports

a.Generate Report

b.Search Report

\section{User DB}

a.Senior Manager

b.Manager

c.Site Engineer

d.Contractor

e.Finance Department

f.Control department

g.All Employees

\section{Make Payment}

\section{Message}

a.New Message

b.Incoming Message

c.Search Message

\section{Change Password}

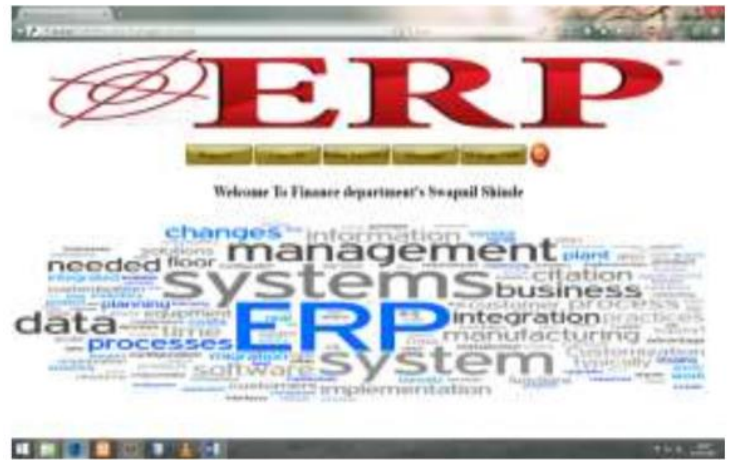

Finance Department

\section{Log Off}

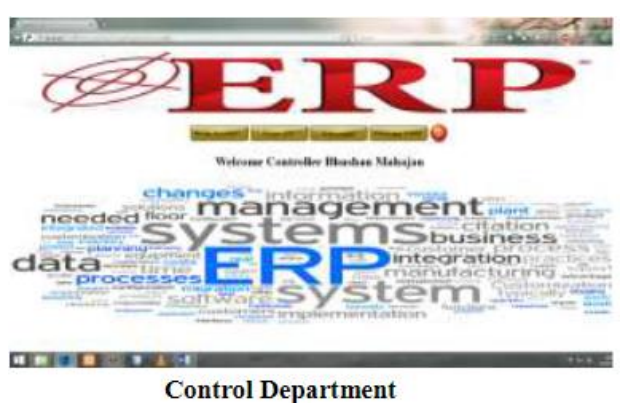




\section{Key Operations}

1.Employee Action

a.Add

b.Update

c.Delete

\section{User DB}

a.Senior Manager

b.Manager

c.Site Engineer

d.Contractor

e.Finance Department

f.Control Department

\section{Message}

a.New Messages

b.Incoming Messages

c.All Messages

\section{Change Password}

\section{Log Off}

\section{V.CONCLUSION}

In this paper, we bring forward a new client-Server architecture for website development. We introduce and analyze the superiorities of the Web client-server architecture in detail. I think that the web based client server can provide a good choice for developers.

\section{ACKNOWLEDGMENT}

The undertaking of a project involves spirit \& hard work. The perfect combination of the both these lead to success. I am highly indebted to all the concerned people who have helped us in the course of our project by their valuable guidance \& knowledge that motivated me to complete our project successfully.I take this opportunity to thank the staff who had made the engender as modest success. I should like to thanks our head of dept. prof. Vaishali Londhefor her patience of bearing our problem and for providing his quick solutions. I own our sincere thanks to our project guide Ms.Gaytree Naikwithout whose help our project would have been an unaccomplished task, madam not only helped us but also encouraged us in the project work. I would also like to thank our principal Dr.Pandharinath Ghungefor his continuous encouragement

\section{REFERENCES}

[1].2013 International Conference on Computational and Information SciencesIEEE paper on The Solution of Enterprise ERP Based on Six-tier Architecture

[2].Implementation. IEEE Software, May/June, 30-36.

[3].Kalakota, R. and Robinson, M. (1999). E-Business Roadmap for Success.

[4].Boston, MA: Addison-Wesley.

[5].Kumar, K. and Van Hillsgersberg, J. (2000). ERP experiences and evolution 